\title{
RESEARCH
}

Open Access

\section{Class structure and income inequality in transitional China}

Xin Liu

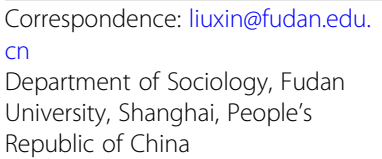

Correspondence: liuxin@fudan.edu. Department of Sociology, Fudan University, Shanghai, People's Republic of China

\begin{abstract}
Integrating Kornai's concept of coordination mechanism and Weber's types of domination, the author argues that, based on the different property rights embedded within the state power structure, bureaucratic and market coordination define class positions in bureaucratic domination by virtue of authority and in market domination by virtue of market capacity. Class relations are defined as relations of domination and economic interest distribution. A class framework composed of 16 class positions is constructed in terms of authority or market capacity in dual domination. The seven-class scheme generated by aggregation of the 16 class positions fits well with a four-cluster model estimated with latent class analysis of the 2010 CGSS, suggesting that the proposed framework is empirically relevant. The statistical findings also show that, compared to advanced industrialized societies, China has a larger proportion of command classes, a relatively equal share of new and old middle classes, and a smaller working class. China has significantly more farmers, especially in the central and western regions. The class structure is oliveshaped in the eastern region but "圭" (gui)-shaped in the central and western regions. The proposed class scheme can significantly predict income inequality, supporting the argument that class relations have the character of a "dominationinterest duality."
\end{abstract}

Keywords: Class structure, Stratification, Class framework, Income inequality, Latent class Analysis, China

\section{Introduction}

How to delineate the class structure in transitional China remains a puzzle. Most researchers have applied neo-Marxist E. O. Wright's class scheme (Wright 1985) or Goldthorpe's neo-Weberian class framework (Goldthorpe 1987; Erikson and Goldthorpe 1992) - directly or with slight modification-to elucidate the class structure in contemporary China. For example, while Lu and colleagues (Lu ed. 2002) altered Wright's class framework in their analysis, Li (2005) and Zhang (2008) both borrowed from Wright in their research. Furthermore, Lin and Wu (2010) attempted to extend Wright's framework to fit Chinese society, and Li et al. (2012) constructed a schema of authority classes for Chinese urban society, an extension of the neo-Weberian framework. These extant studies have gone far in illustrating the class structure in

(c) The Author(s). 2020 Open Access This article is licensed under a Creative Commons Attribution 4.0 International License, which permits use, sharing, adaptation, distribution and reproduction in any medium or format, as long as you give appropriate credit to the original author(s) and the source, provide a link to the Creative Commons licence, and indicate if changes were made. The images or other third party material in this article are included in the article's Creative Commons licence, unless indicated otherwise in a credit line to the material. If material is not included in the article's Creative Commons licence and your intended use is not permitted by statutory regulation or exceeds the permitted use, you will need to obtain permission directly from the copyright holder. To view a copy of this licence, visit http://creativecommons.org/licenses/by/4.0/. 
transitional China. However, the validity of both Wright's and Goldthorpe's class schemes faces a challenge in the unique institutional settings of China's socialist market economy.

For his part, Wright takes control and exploitation within the social relations of capitalist production as central issues in class analysis, defining class positions in terms of their relations to the means of production. Unequal possession of capital, as well as organizational and skill assets, form the basis of exploitation, which translates into a social relation of control over labor and thereby determines how much economic surplus a class position can seize, which manifests as income inequality (Wright 1979, 1985).

Wright's class scheme is based on the premise of a free market system and private production organizations under advanced capitalism; however, the mode of production in transitional China is a complex hybrid. The market is embedded in the state authority structure, there is a huge public sector, and agricultural workers still account for nearly $50 \%$ of the labor force. Therefore, in transitional China, neither the institutional settings at the macro level nor the arrangement of property rights of enterprise at the micro level aligns with the preconditions of Wright's scheme.

The neo-Weberian class approach (Erikson and Goldthorpe 1992; Goldthorpe 1987) adheres to Max Weber's idea of defining class relations as the relations of domination (Weber 1978). Both employment relations in enterprise organizations and exchange relations in the market are relations of domination. For neo-Weberian class theorists, the central issue is to reveal how relations of domination lead to differences in individual class positions and life chances. Members of a society have different assetsincluding economic, professional, and human assets-and thereby have different market situations in market exchange and different working situations in enterprise organizations. In terms of the construction of the class scheme, neo-Weberians emphasize the working situation and its measurability while neglecting the market situation, simply using employment relationships to measure the working situation and thus forming the widely used Goldthorpe framework (Erikson and Goldthorpe 1992; Goldthorpe 1987, 2007).

In addition to the above problems, Wright's scheme has encountered, when applied to Chinese society, Goldthorpe's framework faces the problem of income distribution due to its emphasis on relations of domination. The framework lacks a theoretical explanation for the relationship between class positions and income inequality (Sorensen 1991). Empirical research has also found that there is no significant difference in income between the middle class and the working class when Goldthorpe's framework is directly used to understand contemporary China (Zou 2015).

Integrating Kornai's coordination mechanism (Kornai 1992) and Weber's types of domination (i.e., domination by virtue of authority and domination by virtue of a constellation of interests) (Weber 1978), I argue that class positions, as structural social positions independent of individuals (Sorensen 1991; Simmel 1908), are defined by a bureaucratic dominant-subordinate relationship and a market dominant-subordinate relationship. These two kinds of relationships are respectively based on a bureaucratic coordination mechanism and a market coordination mechanism generated from a deeper institutional arrangement of the property regime in a transitional society. Only by achieving a social position as such does a person obtain a class position and the related control rights over income distribution, thereby securing the related income. 
Thus, class relationships as such defined have the characteristics of "domination duality" and "domination-interest duality." The former refers to class relations composed of a bureaucratic dominant-subordinate relationship and a market dominant-subordinate relationship (respectively termed "bureaucratic class relation" and "market class relation"), while the latter means that the class relation is, on the one hand, a dominant-subordinate relationship and, on the other, a relationship of economic interest distribution.

In earlier studies, I proposed an institutional framework of class structure in urban China (Liu 2006, 2009, 2010, 2012). Composed of 17 class positions and five or six class categories (Liu 2010, 2012), the framework evinces the importance of institutional arrangements of class positions (Goodman 2014; Lui 2015; Zou 2015). However, the framework has encountered problems when applied to other studies. It is exclusively concerned with urban society and does not address the class positions of agricultural contractors and workers. Further, in creating the institutional framework, I did not maintain a consistent logic in combining the 17 class positions and in further aggregating them into the five or six big classes. In generating the map of 17 class positions, I designated the public authority rank at or above the $J u$ (assistant bureau) level, which resulted in a very small proportion of members in this position. Additionally, the classification of professionals must draw on their job title, which requires more information from the survey, thus affecting feasibility.

This study attempts to extend my formerly proposed class framework to produce a new version that applies to the overall society (urban and rural) of transitional China, provides a more consistent logic for the categorization of big classes, and offers a more adequate measure. The empirical relevance of the proposed class framework was tested with results from latent class analysis (LCA) of the 2010 Chinese General Social Survey (CGSS). ${ }^{1}$ Having established its reliability, I used this framework to present the class structure in contemporary China, revealing the relationship of the distribution of economic interests among classes through the analysis of income.

\section{Institutional arrangement and class relation}

In theorizing the possession of the property to be the foundation of class cleavage, Marx and Weber generated the cornerstone of class analysis (Marx 1974: 1000; Weber 1978: 927). I depart from this premise to examine reality in contemporary China. I examined the impact of the arrangement of property rights on class relationships because possession is only one dimension of property rights (Pejovich 1995: 66).

\section{Property rights, coordination mechanisms, and the relations of domination in a transitional society}

Property rights are relations among individuals that arise from the existence of scarce resources and the use of these resources (Pejovich 1995: 66). Property rights also define the position of each individual with respect to the utilization of resources. Scarce resources might refer to access to economic assets or the availability of human capital. Property rights can be partitioned into constituents of the rights to residual income, rights of transferability, and rights of control (Kornai 1992: 62-67). The holder of property rights

\footnotetext{
${ }^{1}$ For an introduction to the CGSS, please see http://www.cnsda.org/. Statistical results reported in this paper are all weighted by the weight variable provided by the original source of data.
} 
can be an individual or a legal entity, which then determines whether the ownership is private, communal, or state-owned. Elements of the ownership of property rights include exclusivity, transferability, and constitutional guarantees (Pejovich 1995: 66). Therefore, the exercise of property rights depends on the state's development and enforcement of a constitution or rules to protect property rights and contract rights (North 1981). This institutional arrangement is especially relevant in a socialist market economy because the characteristics of the socialist power structure are the fundamental source from which the chief regularities of the system can be deduced (Kornai 1992: 33), and because the political structure of power and the arrangements of property rights jointly determine the part that various coordination mechanisms play (Kornai 1992: 91). Thus, I base my analysis of the relations between property rights and class positions on deeper institutional settings, that is, the relations between the state political structure and the arrangements of property rights, and then assess class relations through analysis of the coordination mechanism in China's transitional society.

A coordination mechanism manages the activity of persons or organizations (Kornai 1992: 91). Bureaucratic coordination and market coordination play the most important roles in a transitional society, such as China. ${ }^{2}$ The former has an affinity with state public property, while the latter has an affinity with private property (Kornai 1992: 103). In bureaucratic coordination, the relations between coordinator (an individual or an organization) and the coordinated are vertical linkages, usually manifested as a multilevel superior-subordinate hierarchy, in which an individual or an organization at a certain level is at once the superior of the level below and the subordinate of the level above. The subordinate is appointed by and obeys the superior, and the motivation for carrying out the superior's command is to win the superior's approval, receive the reward offered, and avoid the penalty for noncompliance (Kornai 1992: 91-92). In market coordination based on private property, the seller and the buyer have horizontal linkages rather than vertical command relations. A contract is reached on a mutually voluntary basis, and both parties seek an economic gain from the transaction (Kornai 1992: 92, 447-450).

Before the reform in 1978, the public economy had an overwhelming advantage in China, while the private economy was very small. Bureaucratic coordination played a predominant role in political, economic, and social organizations. After the reform, as the private economy became legalized and gained ground, market coordination became increasingly important. Meanwhile, public property rights were partitioned to a certain degree to be transacted by market coordination. Notably, the coordination mechanism is not limited to within an organization. In a socialist system, the party-state agency can coordinate the relation between almost any organization and individual.

In contemporary Chinese society, bureaucratic coordination plays a dominant role in the Communist Party of China (CPC), government, and state-owned nonprofit organs. In publicly-owned (or publicly-held) enterprises, bureaucratic and market coordination work jointly, but with the former being primary because the public property is managed by a principal-agent model that is administrative and contractual (Liu 2006, 2009). As

${ }^{2}$ In addition to bureaucratic and market coordination mechanisms, Kornai (1992: 91) lists self-governing, ethical, and family coordination mechanisms; however, he maintains that, due to the constraints of ideology and political structure, self-governing, ethical, and family coordination, although present to a certain degree, are relatively weak or marginalized (Kornai 1992: 103-106). Thus, bureaucratic and market coordination are the most dominant mechanisms in a transitional society. 
such, the arrangement of public property rights has transformed into joint-stock ownership, and government and enterprise have been partially separated (Qian and Wu 2008). To some extent, such institutional structures enable the market transaction of public property rights. However, the authority for appointments and dismissals, asset management, and investment decision-making in state-owned (including state held) corporations is still in the hands of different governmental departments (Yang 2014; Wu 2010; Chi 2014), thereby sustaining bureaucratic coordination.

Market coordination dominates the private sector. However, a socialist market is strongly embedded in the structure of state authority. This arrangement, on the one hand, helps the state retain the authority to intervene through direct or indirect means (e.g., through the industry association) in private enterprises' market access, financing channels, and social credits (Wu 2010: 173-175) and, on the other hand, constrains the free transaction of human capital through the system of household registration, labor and personnel, social security, etc. Therefore, the state plays a certain bureaucraticcoordination role in the transaction of private property rights.

The coordination mechanism that conforms to the political structure and property regime further determines the relations of domination between organizations and individuals. Drawing upon the two types of domination Weber distinguished (1978: 941-948) (i.e., "domination by virtue of authority" and "domination by virtue of a constellation of interests"), I explicate how the coordination mechanism defines the relations of domination.

Weber's domination by virtue of authority denotes the power relation in which the dominant is able to legitimately issue commands that the subordinate has the duty to obey. This kind of relationship does not involve the domination formed from free market competing exchange motivated by rational economic interests (Weber 1978: 946). In modern society, domination by virtue of authority exists widely in organizations such as political parties, economic enterprises, churches, and clubs (Weber 1978: 223). Obviously, the bureaucratic coordination mechanism described by Kornai is very similar to Weber's domination by virtue of authority. Thus, I contend that the links among participants in bureaucratic coordination assume a dominant-subordinate relationship structure, widely existing across social organizations and individuals. ${ }^{4}$

In contemporary Chinese society, social positions are defined by the bureaucratic dominant-subordinate relationship in organizations where bureaucratic coordination

\footnotetext{
${ }^{3}$ Weber sees classes, status groups, and parties as phenomena of the distribution of power within a community (Weber 1978: 927). However, Weber does not identify classes directly in terms of power. He thinks that the sense of power is too broad to be used in understanding the structure of dominance (Weber 1978: 943). Rather, he focuses more on domination, which is connected to stable and sustained social relations.

${ }^{4}$ Both Wright and Goldthorpe noted domination relations inside work organizations in their frameworks. The theoretical logic that emphasizes intra-organization domination in class analysis is related to Lockwood's (1958) argument about market situation, work situation, and status situation. His research focused on the market situation complemented by the work situation and status situation. However, later researchers, such as Goldthorpe, used the concept of the work situation to develop Weberian class theory, highlighting the operationalization of this concept. For Goldthorpe, the work situation has almost become a one-dimensional form of domination as employment relations. Wright's concept of an organizational asset is also connected to the power distribution in employment relations. Goldthorpe's and Wright's class frameworks both aggregate occupations that have the same employment position into bigger classes and so can be seen as adopting an "employment-aggregation approach" to class analysis (Crompton 2008; Vogt 2018). However, the sense of the work situation concerning labor division and tasks and its relationship with the market situation has been neglected because of the emphasis on the operationalization of domination in the form of employment (Breen 2005; Crompton 2008; Vogt 2018).
} 
dominates. The state or its agent carries out bureaucratic coordination within the scope of public authority, including the appointment of cadres, management of enterprises and institutions, control of social organizations, and supervision of farmers, individual vendors, and freelancers. At the end of 2013, governmental and public institutions in China amounted to 1.037 million, accounting for $9.6 \%$ of all corporate bodies; 1.611 million social organizational and other corporate bodies constituted $14.8 \%$, while 113 thousand state-owned corporations and 131 thousand collective enterprises made up $1.4 \%$ and $1.6 \%$, respectively. ${ }^{5}$ These organizations, to some degree, have bureaucratic coordination and bureaucratic dominant-subordinate relationships.

Weber's domination by virtue of a constellation of interests refers to the dominantsubordinate relationships among market participants in rationally competitive exchange for economic interests. According to Weber, some people own property, while others lack property except their own labor capacity; these are the preconditions for the establishment of market domination. "It is possible for the same thing to be true of a market economy, though in a formally voluntary way. This is true wherever the unequal distribution of wealth, and particularly of capital goods, forces the non-owning group to comply with the authority of others in order to obtain any return at all for the utilities they can offer on the market-either with the authority of a wealthy householder or with the decisions, oriented to capital accounting, of the owners of capital or of their agents."(Weber 1978: 109-110)

As such, in market coordination, although the transaction of property rights is a horizontal linkage and the parties involved reach a voluntary contract, there is still a dominant-subordinate relationship. In other words, the relationship among participants in market coordination manifests as a market dominant-subordinate model, which defines participants' market situation-that is, the economic position consisting of source and size of income, degree of job security, and opportunity for upward occupational mobility (Lockwood 1958: 15).

The private sector accounts for the main component of the current Chinese economy. By the end of 2013, out of the 8.2 million registered corporate bodies, non-state-owned and collective corporations made up $93.7 \%$. Domestic private corporations numbered 5.6 million, making up $68.3 \%$ of all registered corporate bodies. Foreign, Hong Kong, Macau, or Taiwan corporations made up $2.5 \%$ of the total with 203 thousand. Certified ge ti hu (self-employed firms) amounted to 32.79 million. ${ }^{6}$ Considering ge ti hu that had not formally registered, the actual number must have been even larger. Moreover, household responsibility contracts are signed for 30 years, which makes contracting families de facto private farmers. The transaction of property rights in the private sector is dominated by market coordination. Therefore, depending on their control over property rights, participants in the private sector end up in different positions as defined by the dominantsubordinate relationships in the market.

\footnotetext{
${ }^{5}$ The Bureau of Statistics of the People's Republic of China, the Office of the Third National Economic Census Leading Committee of the State Council, "Public Bulletin of Main Statistics in the Third National Economic Census (Number One)," published on December 16, 2014. (www. stats. gov. cn/tjsj/zxfb/201412/ t20141216_653709.html)

${ }^{6}$ The Bureau of Statistics of the People's Republic of China, the Office of the Third National Economic Census Leading Committee of the State Council, "Public Bulletin of Main Statistics in the Third National Economic Census (Number One)," published on December 16, 2014. (www. stats. gov. cn/tjsj/zxfb/201412/ t20141216_653709.html)
} 
The relations of domination and class position

Thus far, I have discussed the two types of relations of domination-the bureaucratic dominant-subordinate relationship and the market dominant-subordinate relationshipthat are determined by the coordination mechanism in conformity with the political structure and property regime in contemporary China. These domination relationships further define the various structural social positions within and across organizations and institutions. These positions are class positions. Table 1 shows the relationships between property rights, the coordination mechanism, and class positions.

In party and governmental agencies, publicly-owned (or publicly held) enterprises, and public nonprofit organizations, bureaucratic coordination dominates, while market coordination plays a secondary role. Incumbents of the dominant positions are directing cadres, the chairmen of the boards, general managers, or leaders in charge of the institutions. By contrast, subordinate positions are held by employees and workers (including employees and workers of the subordinate institutions). Between dominants and subordinates are middle-class positions occupied by functional and administrative staff, departmental managers, clerks, and professionals. I term this type of class relationship a "bureaucratic class relation" (i.e., the bureaucratic dominant-subordinate relationship based on bureaucratic coordination).

While market coordination dominates privately owned (or privately held) enterprises and institutions, self-employed firms, and rural household responsibility contract businesses, bureaucratic coordination also plays a role. In these organizations, shareholders, business owners, major departmental leaders, or village leaders hold the dominant positions, while employees and workers are the subordinates. Departmental managers, managerial and administrative staff, professionals, the self-employed, and household contractors are in middle-class positions. I call such class relations a "market class relation" (i.e., the market dominant-subordinate relationship based on market coordination).

Obviously, class relations in contemporary Chinese transitional society are qualified by "domination duality."

\section{Class position and economic interest}

Income distribution is a crucial topic for class theory (Sørensen 1991, 2000; Szelenyi and Kostello 1998; Wright 1979, 1985; Wodtke 2016). ${ }^{7}$ Since class position is based on property rights consisting of the rights of control (management, decision-making, and supervision of the property), transferability (sell it, rent it out, present it as a gift to others, or bequeath it to heirs), and residual income (dispose of the income generated by the property) (Kornai 1992: 64-66), there exists an income distribution relation between class positions. In the transitional economy, the primary source of income inequality is the dominating coordination mechanism ${ }^{8}$.

In the phase of the planned economy in China, the principle of distribution "to each according to his work" was practiced. Since the reform, with the change of the

\footnotetext{
${ }^{7}$ A major critique of Goldthorpe's class framework is that it emphasizes employment relations but lacks a theoretical explanation of the relationship between class positions and income (Sørensen 1991).

${ }^{8}$ Szelenyi analyzes the inequality in state socialism and transitional society (Szelenyi 1978; Szelenyi and Kostello 1998), building on Polanyi's (1944, 1957a, 1957b) concept of economic integration (redistribution, market, and reciprocity). Although expressed differently, it is similar to Kornai's concept of a coordination mechanism. Kornai maintains that bureaucratic coordination is a broader concept than redistribution (Kornai 1992:96).
} 


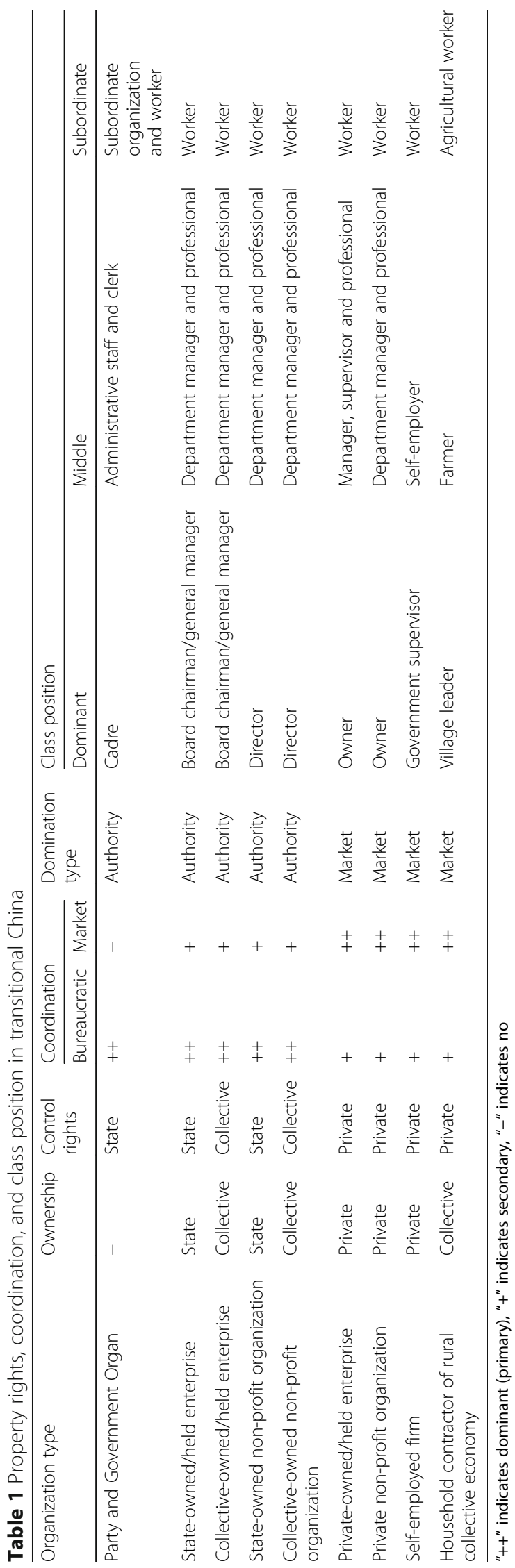


Table 2 Power basis of class position and its economic interests

\begin{tabular}{lllll}
\hline Class position & $\begin{array}{l}\text { Ownership of } \\
\text { economic capital }\end{array}$ & $\begin{array}{l}\text { Control rights of } \\
\text { economic capital }\end{array}$ & $\begin{array}{l}\text { Control rights of } \\
\text { human capital }\end{array}$ & $\begin{array}{l}\text { Control rights } \\
\text { of income }\end{array}$ \\
\hline $\begin{array}{l}\text { Party and government organ and public } \\
\text { institution cadre }\end{array}$ & - & + & + & + \\
$\begin{array}{l}\text { SOE/SCE board chairman/general } \\
\text { manager }\end{array}$ & $+/-$ & + & + & + \\
POE board chairman/owner & + & & & + \\
POE manager & $+/-$ & + & + & + \\
Self-employed & + & + & - & + \\
Farmer & $+/-$ & + & $+/-$ & + \\
Professional & $+/-$ & $+/-$ & $+/-$ & $+/-$ \\
Worker & - & - & - & - \\
\hline
\end{tabular}

"+" indicates yes, "-"indicates none, "+/-"indicates some or none

arrangement of property rights, it has gradually become legitimate for productive factors, such as labor, capital, technology, and management, to participate in the distribution of income in accordance with their respective contributions. In Table 2, I show how major class positions based on the property rights of economic assets and human capital can control the rights over residual income.

Productive factors, such as labor, land, economic capital, and entrepreneurship, can at the initial stage (in the primary market) form business organizations through either bureaucratic coordination or market coordination. After that, they become internal elements of the established business organization and must be coordinated by bureaucratic or market mechanisms.

In market class relations, which are determined by market coordination, payoffs for owners of the labor force, land, economic capital, and entrepreneurship are, respectively, wages, rent, interest, and profit (i.e., the price for using these productive factors, obtained through free market transaction) (Quan 2017: 119-158).

For workers, physical strength and labor skills are the sources of wages. For professionals and technicians, their knowledge and skills are the sources of their salary. Their wages or salary reflects human capital prices that are determined by the supply-demand relation in the labor market (the labor markets both within and outside the business organization). Professionals differ from workers in that they have more human capital and therefore are more likely to obtain control rights over the labor force (strengths or lower labor skills) of workers, and accrue related payoffs. They may also secure market payoffs using technological patents or stock shares.

Land lacks supply elasticity. A land owner's payoff is rent, that is, the price of production factors with a fixed supply. Although rural land is collectively owned by the village in contemporary China, agricultural household contractors have become de facto private farmers because of the long duration of contracts and the fact that utilization rights can be transferred within the contract period. Farmers have class positions similar to those of small private business owners or the self-employed and can obtain rent from transferring the rights to use their land or contracted collective assets to others.

Owners of economic assets (such as factories, equipment, and money) enjoy the rights of transferability and control and thereby can control other people's human capital and the control rights of residual income. Thus, they can either invest economic 
assets into their own enterprises for the payoff (like small business owners and the selfemployed) or transfer the utilization rights of their economic capital to others for an interest payment (like private shareholders and large business owners). The price of economic capital also depends on its market supply and demand.

Different from wages, interest, or rent, entrepreneur revenue is a functional payoff generated when the entrepreneur's talent has fulfilled a certain function in the production process (for example, performing as business manager). Entrepreneurs, because they enjoy the control rights over economic capital, have control rights over other people's human capital and thus control rights over residual income.

In bureaucratic class relations that are determined by bureaucratic coordination, the transaction of property rights can be seen as a "non-market transaction" (Polanyi 1944, 1957a, 1957b; Szelenyi 1978). In nonmarket transactions, business surplus deviates from the competitive market price and thereby can be seen as rent. ${ }^{9}$

Although cadres of party and government organs do not directly control the property rights of public enterprises and institutions, they can rely on bureaucratic coordination mechanisms to indirectly control investment decisions, asset disposal, and personnel appointment and removal through government agencies or the State-owned Assets Supervision and Administration Commission (SACAC). Therefore, they can control the related residual income on behalf of the state. Moreover, they constrain the enforcement of private economic property rights through tax rates, business licenses, market interventions, and public services, thereby controlling, on behalf of the state, the rights to collect taxes or seize rents. In addition, through systems such as household registration, credential assessment, and human resource management, these party and government organs play a protective or restrictive role in the transaction of human capital and-again, on behalf of the state-control the rights over rents generated from human capital transactions. As such, those in the leadership positions of the party and government organs have the right to control taxes or rent because they hold dominant positions in bureaucratic class relations.

The chairman of the board or the general manager of a state-owned (or state-held) company or a collective (or collectively held) company has direct control rights over public assets and thereby direct control rights over human capital and residual income.

In sum, class relations in contemporary China are not only the relationships of domination but also the relationships of the distribution of economic interests. There is a duality of relations of domination and economic distribution. On the one hand, there is a double relationship of domination (i.e., consisting of a bureaucratic class relation and a market class relation); on the other hand, the class relation is an income distributive relation. Therefore, to delineate the class structure of current Chinese society, we must first identify basic class positions in domination relations (bureaucratic class relation and market class relation) and further distinguish the positions of the subclasses within the

\footnotetext{
${ }^{9}$ For discussions about the political embeddedness of property rights and the state's extraction and redistribution of rents, see Liu $(2006,2009)$. Political embeddedness causes the state erosion of the property rights of economic assets and human capital, leading labor capital to integrate with factors of production in non-market trade. Business surplus exists in the form of rent. Public power manifests not only as the right to control rents but also as the authority to redistribute these rents. The redistributors tend to prefer themselves and their loyalists in the distribution, resulting in class inequality. Market class relations also have the element of interest distribution. Market capabilities based on economic capital, skill, or labor power all form different abilities to seek rent through competitive market exchange. Sørensen (2000) presents a systematic discussion of class exploitation based on property rights that produce rents.
} 
basic class positions. Then, it is necessary to analyze the interest relationship across various classes and reveal the income disparity among them.

Although the basic classes are distinguished as dominant or dominated and advantaged or disadvantaged, subclass positions in one basic class position may overlap with subclass positions in another basic class position in terms of the income they enjoy. Thus, the classes and subclasses we distinguish here are selected mainly to demonstrate the model of the relationship among them, rather than to arrange the classes and subclasses into a ladder.

\section{A class framework for society in transitional China}

The class framework shown in Fig. 1 illustrates the social relations among different classes. The basic principles of classification implied in the framework include (a) in bureaucratic class relations, whether a social position enjoys public authority (including party-state authority and control rights over public assets) and the level at which it has authority in the bureaucratic hierarchy; and (b) in market class relations, whether a social position has market power (including capacity based on the property rights of economic assets and capacity based on the property rights of human capital) and the level of market power it has. Importantly, this class framework distinguishes structural positions in bureaucratic and market domination relations-that is, the institutionalized social positions that enjoy different levels of power in the bureaucratic hierarchy and market exchange-rather than the categorical aggregation of individuals with various occupations. By occupying these social positions, individuals enjoy corresponding power and income.

First, in bureaucratic class relations, we can distinguish two basic categories: "social position with public authority" and "social position without public authority." Between these are the functional "administrative positions," whose typical members are public sector staff and clerks. Although staff and clerks do not possess direct authority in bureaucratic class relations, they are close to the dominant and convey the authority of the dominant (Lockwood, 1958:81) and thus occupy positions between the dominant and the subordinate. Similarly, in market class relations, staff and clerks are posited between managers and workers.

Second, social positions with public authority can be divided into two types according to whether they have direct control rights over public economic assets: dominant

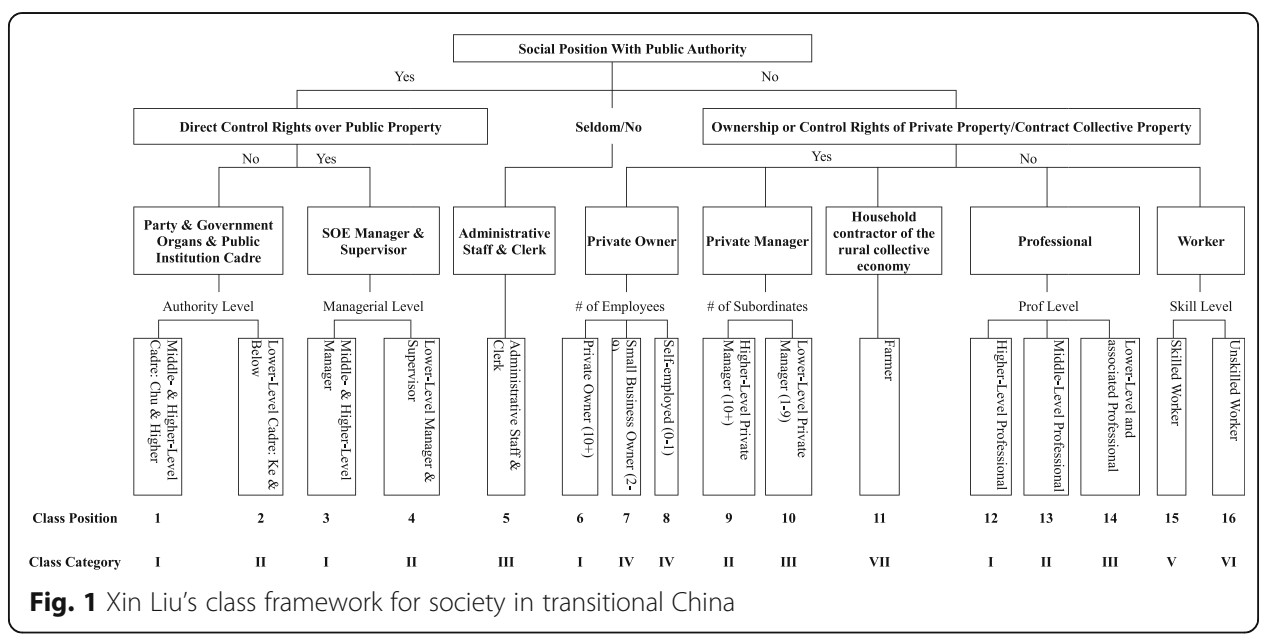


positions in the party and government organs and public institutions without direct control rights over public property and dominant positions in publicly-owned (or publicly held) enterprises with direct control rights over public property. Dominant positions without direct control rights over public property can be further divided into the middle- and higher-level posts (deputy chu rank and above) and the below-middlelevel posts ( $k e$ rank and below) in terms of their authority ${ }^{10}$. Indirect control over public assets and direct control over human capital grants the incumbents of these dominant posts control rights over business revenue. Similarly, the dominant positions in publicly-owned (or publicly held) enterprises can be divided into the middle- and higher-level management roles (deputy chu rank and above, or equivalent managerial rank) and the below-middle-level management roles (ke rank and below, or equivalent managerial rank). Managers in these dominant positions directly control over the public property and the human capital of others, which enables them to assume power over business revenue. In addition, these public firm managers enjoy some market power and related rights over business income because the public assets they control are-to a certain extent-exchangeable in the market in a transitional economy.

Third, the social positions without public authority can be further divided into two categories: one is the dominant social position with ownership or control rights of private property in private (or privately held) enterprises; the other is the subordinate social position without such rights. In addition, farmers can be regarded as de facto private owners of land or other means of production because they are allowed to contract the village collective land or other agricultural means of production for a very long term.

The social positions with ownership or control rights of private property can be further divided into two types of social roles according to the source and size of market capacity. The first type consists of employers, managers, and farmers and is characterized by ownership or control rights of private economic assets. The second type consists of professionals and workers and is characterized by a lack of ownership or control rights of private economic assets. I classify the former type of social role into concrete class positions in terms of the size of ownership or controlling rights over economic assets and the later type into class positions in terms of the amount of human capital. ${ }^{11}$

Because of the ownership of economic assets, the employer has the market capacity to control the human capital of others and, therefore, can control related business revenue. Therefore, according to their market capacity to control the human capital of others, employers can be divided into private entrepreneurs (with 10 or more employees), small business owners (with 2 to 9 employees), and self-employed (with 0 or 1 employees).

Private enterprise managers have the market capacity to control the human capital of others due to their control rights over economic property granted by the employer,

\footnotetext{
${ }^{10}$ China's bureaucratic cadre grade system has mainly 5 ranks (from top to bottom): senior CPC and state governmental officials (prime minister and head of the state and the central committee of CPC), bu-rank (head of ministry and provincial leader), ju-rank (head of bureau and prefecture leader), chu-rank (head of division and county leader), and ke-rank (head of section and township leader). Each rank is divided into the principal and deputy posts. In addition, there are some non-ranked officials below the ke-rank, titled gu-rank or clerks, that do not belong to the official bureaucratic grade system.

${ }^{11}$ The classification of professionals and workers refers to the occupational code Goldthorpe and colleagues developed in the CASMIN project (see Ganzeboom and Treiman, 2003). This study differs from theirs in that professionals are divided into higher-level professionals (those engaged in theoretical research and creation), middle-level professionals, and lower-level and associated professionals.
} 
thus also enjoying - to a certain extent-control rights over related business revenue. For private enterprise managers, based on their market capacity to control the human capital of others, I distinguish between middle- and higher-level managers (with 10 or more direct subordinates) and lower-level managers (with 1 to 9 direct subordinates).

The source of income for both professionals and workers is human capital, but professionals (especially higher-level professionals) have a much higher amount of human capital than workers, which may enable them to control the human capital of others and thus, to some degree, hold rights over business revenue. Professionals are divided into higher-level, middle-level, and lower-level and associated professionals. Workers are also classified according to their skill level as skilled workers and unskilled workers.

Explicating the class position of farmers in the current institutional settings of the Household Contract Responsibility System in China is a complex task. We could see them as the self-employed, along with small and self-employed business owners, because they have de facto private property rights over village land and/or other agricultural means of production thanks to their very long-term contract rights to these village collective economic assets. We could also see them as agricultural managers because they only have control rights, not ownership, of the agricultural means of production. In both scenarios, farmers are not laborers in the sense of agricultural labor workers because they have control rights over business revenue. The employed agricultural worker category, in its pure sense, only applies to those who engage in the agricultural, forestry, animal husbandry, or fishing industries but have not contracted any of these collective assets. These people, much like industrial workers, have no control rights over business revenue.

As such, we have distinguished 16 class positions. The Additional file 1 to this paper shows a Stata do-file for generating the class framework for society in transitional China using the 2010 CGSS.

By clustering the 16 class positions according to their level of bureaucratic authority or market capacity, I constructed a class scheme consisting of seven big classes: (1) the command class (the upper class), (2) the new upper-middle class, (3) the new lowermiddle class, (4) small business owners and the self-employed, (5) skilled workers, (6) unskilled workers, and (7) farmers (household contractors of the agricultural, forestry, animal husbandry, or fishing industries).

The relations among these seven classes include dominant-subordinate relations as well as relations of economic interest distribution. Classes in the dominant position also enjoy advantages in the distribution of business revenue. The command class, small business owners and the self-employed have control rights over business income, while skilled and unskilled workers do not; the new middle class sits in the middle, with certain levels of control rights over business revenue.

As the dominant class in a transitional society, the command class is in the dominant position in both bureaucratic class relations and market class relations. It consists of middle- and higher-level leaders in the party and government organs, middle- and higher-level managers in publicly-owned (or publicly held) enterprises and institutions, private entrepreneurs, and higher professionals. Moreover, the command class has control rights over business revenue and thus may have an advantage in income distribution. At the other end of the spectrum, the dominated class, including skilled and unskilled workers in manufacturing, services, and agriculture, is in a subordinate 
position in bureaucratic or market class relations. The dominated class has no control rights over business revenue and therefore is disadvantaged in income distribution.

Between the two basic classes-the dominant class and the dominated class-is the middle class. Following Mills (1951), I distinguish between the new middle class and the old middle class. Unlike the old middle class, such as small business owners or private farmers, the new middle class consists of managers, professionals, and white-collar employees who do not have private economic assets and are hired and live on salaries.

The new middle classes can be further divided into the new upper-middle and the new lower-middle classes according to their rank of bureaucratic authority or quantity of market capacity based on control rights over economic assets or based on human capital. The new upper-middle class consists of the below middle-level leaders in the party and government organs, below middle-level managers in publicly-owned (publicly held) enterprises and institutions, and middle-level professionals, etc. The new lower-middle class contains the functionaries and staff in the party and government organs, grassroots supervisors and clerks in publicly-owned (publicly-held) enterprises and institutions, lower-level and associate professionals, lower-level managers in private enterprises, private small business managers, etc. Whether upper- or lower-middle class, the common feature of the middle class is their position between the dominant and the dominated in either bureaucratic class relations or market class relations. In addition, in terms of business revenue distribution, they sit between the advantaged and the disadvantaged. Compared with the command class, they have relatively fewer control rights over business revenue, but compared with the working class, they have at least some control rights over business revenue.

Unlike the new middle class, the old middle class (small business owners and the self-employed) own private economic assets, but due to their limited economic capital, they have less market capacity than large private owners and managers as well as managers of large publicly owned (or publicly held) corporations. Therefore, in market class relations, they are between the owners (or managers) of large corporations and the working class. Moreover, they have control rights over their own business income.

In the institutional context of the Household Contract Responsibility System, as contractors in the agricultural, forestry, animal husbandry, or fishing industries, farmers have de facto private property rights over land or other agricultural means of production; thus, they are in class positions similar to those of small business owners or the selfemployed. However, due to the limited amount of economic assets they control, their market capacity may not be as great as that of the small business owners and the selfemployed; thus, they may be in a more disadvantaged position than the small business owners and self-employed in market class relations.

In addition to clustering into the seven-class scheme, the 16 class positions can be aggregated into other class schemas in application. For example, merging the upperand lower-middle classes, as well as the skilled and unskilled workers, forms five classes (command class, new middle class, old middle class, workers, and farmers).

As another example, consistent with the proposed logic of "domination duality" (bureaucratic class relations vs. market class relations), we can classify the command class into the "public power elite" and the "market power elite" or divide the new middle class into the "bureaucratic new middle class and the "market new middle class". Doing so creates new concepts of "dual elites" or "dual new middle classes" for 
class analysis in transitional China. In addition, not only do the positions of the command class and the new middle class have characteristics of duality but also the paths to the divided command classes and the paths to the divided new middle classes are dual. The mechanism of social mobility leading to the public power elite is distinguished from that leading to the market power elite. Similarly, the social mobility path to the bureaucratic new middle class is different from that to the new market middle class. To highlight these sharp differences, I present two propositions: there are "a dual track to the divided elite positions" and "a dual track to the divided new middle class positions" in a transitional society. My additional articles will be devoted to examining these propositions.

\section{The empirical relevance of the class framework}

In this section, I analyze the 2010 CGSS data with LCA to assess the empirical relevance of the proposed class framework for society in transitional China. LCA assumes that the probability distribution of manifest variables and the correlation between manifested variables can be explained by a latent categorical variable and that this latent categorical variable contains only a small number of mutually exclusive categories. The variation of the value of manifest variables should be explained with a latent variable using as few categories as possible (Vermunt and Magidson 2003). Let $A, B$, and $C$ be three manifest categorical variables with $I$, $J$, and $K$ categories, respectively; $X$ is a latent categorical variable with $T$ categories. Then, $\pi$, the probability that a random observation falls into the cell $i j k t$ in the contingency table with a total number of $\mathrm{I} \times \mathrm{J} \times \mathrm{K} \times \mathrm{T}$ cells, can be expressed as:

$$
\pi_{i j k t}^{A B C X}=\pi_{t}^{X} \pi_{i t}^{A \mid X} \pi_{j t}^{B \mid X} \pi_{k t}^{C \mid X}
$$

in which $i=1,2, \ldots I ; j=1,2, \ldots j ; k=1,2, \ldots K ; t=1,2, \ldots T . A|X, B| X$, and $C \mid X$, each denotes a conditional probability. The above equation shows that the probability $\pi$ is the function of the conditional probability of the latent categorical variable, $X$, being at level $t$, and the manifest variables $A, B$, and $C$ being at levels $i$, $j$, and $k$, respectively. As such, the estimates of conditional probabilities can provide a basis for explaining the meanings of different categories of the latent variable. I use Latent Gold 5.0 to estimate the parameters in the above model.

In LCA, I use the following manifest categorical variables:

(1) The public authority rank: 0-no public administrative position, 1-public administrative position without rank, 2-public administrative position at grass-roots level, 3-public administrative position at middle or higher level.

(2) Control rights over others' human capital: 1-supervises others but not supervised by others, 2-supervises others while being supervised by others, 3-neither supervises others nor is supervised by others, 4-supervised by others but supervises no one.

(3) Ownership of private economic assets: 1-owner of private business, 2-self-employed, 3-employee. 
Table 3 Goodness of fit statistics of the LCA models

\begin{tabular}{llllll}
\hline Model & $\boldsymbol{X}^{\mathbf{2}}$ & $\boldsymbol{P}$ & $\boldsymbol{G}^{\mathbf{2}}$ & $\boldsymbol{P}$ & $\mathrm{df}$ \\
\hline 1-cluster & 115240.5 & 0.000 & 24989.8 & 0.000 & 2287 \\
2-cluster & 18839.2 & 0.000 & 5529.6 & 0.000 & 2270 \\
3-cluster & 5856.8 & 0.000 & 3282.6 & 0.000 & 2253 \\
4-cluster & 2848.4 & 0.000 & 1758.0 & 1.000 & 2236 \\
5-cluster & 2029.6 & 1.000 & 1354.2 & 1.000 & 2219 \\
\hline
\end{tabular}

(4) Control rights over income, measured by three dummy variables, whether the respondents have: 1 -property income (yes $=1$ ), 2-wage income (yes $=1$ ), 3-income from agricultural, forestry, animal husbandry, or fishing (yes $=1$ ).

(5) Annual income (RMB): 1-50,000 and more, 2-30,000-49,999, 3-20,000-29,999, 4-10,000-19,999, 5-5000-9,999, 6-less than 5000.

Table 3 reports the goodness-of-fit statistics of the LCA models and their significance levels. The $\chi^{2}$ and $G^{2}$ values and related significance suggest that the 4-cluster model is most parsimonious and fits the data well. I use this model for further analysis.

As shown by the 4-cluster LCA model, cluster probabilities and the indicator conditional probabilities across the five categorical variables reveal the following obvious patterns ${ }^{12}$.

Latent cluster 1 is characterized by respondents who have no public administrative position; neither supervise others nor are supervised by others; have private assets; have income from agricultural, forestry, animal husbandry, or fishing; have no wage income or property income; have an annual income of less than 5000 yuan. Respondents with these characteristics are mostly farmers.

In cluster 2, respondents have either no public administrative position or a public administrative position without rank; they are supervised by others but supervise no one; they are employees and live on wage income; their annual incomes are between 10,000 and 19,999 yuan. Respondents in this latent cluster are mostly staff, clerks, and workers.

Those that fall into cluster 3 either have a public administrative position without rank or have a public administrative position at grassroots level; supervise others while being supervised by others; are mostly employees and live on wage income, but some of them have property income; and have annual incomes of more than 30,000 yuan, with some having even more than 50,000 yuan. Respondents who fit into cluster 3 are belowmiddle-level leaders in the party and government organs, below-middle-level managers in publicly-owned (publicly held) enterprises and institutions, and middle- and lowerlevel professionals.

For cluster 4, members have either no public administrative position or a public administrative position without rank; they neither supervise others nor are supervised by others; they possess economic assets and have some property income; most of them have an annual income more than 20,000 yuan and some even more 50,000 yuan. Those who fit these characteristics are mainly private business owners and the selfemployed.

\footnotetext{
${ }^{12}$ Due to the space limitation, I do not include the table of the latent cluster probabilities and the item conditional probabilities for the 4-cluster LCA model, which is available from the author upon request.
} 
Table 4 reports the row and column contingency percentages between the latent variable with 4 clusters and the proposed class scheme with seven categories. As shown in Table 4, my seven-category class framework that is deductively defined collapses neatly into the four latent type classes derived from empirical induction.

The column percentages show that $79 \%$ of the members of the command class fall into latent cluster 3 (below-middle-level leaders in the party and government organs, below-middle-level managers in publicly-owned (or publicly-held) enterprises and institutions, and middle- and lower-level professionals) or cluster 4 (private business owners and the self-employed). Among them, as the row percentages show, $44.3 \%$ fall in cluster 3 , making up $9.5 \%$ of this cluster, and $34.7 \%$ (most of them are private entrepreneurs) fall in cluster 4 , making up $9.0 \%$ of this cluster. Furthermore, $69.2 \%$ of the members of new upper-middle class fall into cluster 3 , constituting $52.5 \%$ of this cluster; $79.3 \%$ of the new lower-middle class fall into cluster 2 (staff, clerks, and workers), making up $34.6 \%$ of the latent cluster; $52.3 \%$ of small business owners and the self-employed belong to latent cluster 4 , comprising $69.0 \%$ of this latent cluster; another $43.6 \%$ fall into latent cluster 1 (farmers), making up $9.6 \%$ of this cluster. Moreover, $93.7 \%$ of skilled workers and $95.1 \%$ of unskilled workers belong to latent cluster 2, constituting $23.6 \%$ and $34.4 \%$ of this latent cluster, respectively; $98.9 \%$ of all farmers fall into latent cluster 1, making up $89.7 \%$ of this latent cluster. In general, the class scheme I have constructed is highly consistent with the results of the inductive LCA, demonstrating its empirical relevance in contemporary Chinese society.

\section{Class structure in transitional China}

Based on the class framework for society in transitional China shown in Fig. 1, I use the 2010 CGSS data to illustrate the proportion and regional and gender differences for each class position. The results are shown in Table 5.

The differences among the eastern, central, and western regions as well as between men and women are statistically significant (the $\chi^{2}$ for regional difference is 1671.7 with 30 degrees of freedom and $p<0.000$; the $\chi^{2}$ for gender difference is 471.7 with 15 degrees of freedom and $p<0.000$ ). With the exception of household contractors, all class positions have a larger presence in the east than in the center and the west. Among the advantaged classes, men outnumber women, while among staff, clerks, household contractors, and lower and associate professionals, women outnumber men.

Table 4 Estimated two-way margins of 4 cluster LCA models by Xin Liu's class scheme: 2010 CGSS

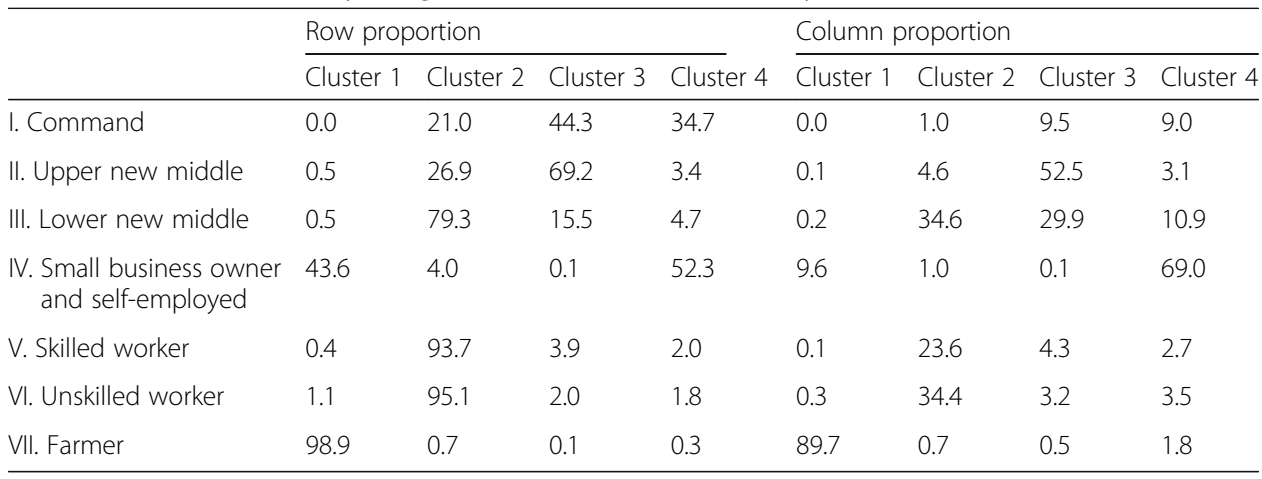


Table 5 Class positions in transitional China: 2010 CGSS

\begin{tabular}{|c|c|c|c|c|c|c|c|}
\hline \multirow[t]{2}{*}{ Class position } & \multirow[t]{2}{*}{ Total } & \multirow[t]{2}{*}{$\%$} & \multicolumn{3}{|c|}{ Region (\%) } & \multicolumn{2}{|c|}{ Gender (\%) } \\
\hline & & & Eastern & Central & Western & Male & Female \\
\hline $\begin{array}{l}\text { 1. Party and government organs and public institution } \\
\text { cadre: middle and higher level }\end{array}$ & 44 & 0.4 & 0.9 & 0.1 & 0.2 & 0.6 & 0.2 \\
\hline $\begin{array}{l}\text { 2. Party and government organs and public institution } \\
\text { cadre: below middle level }\end{array}$ & 235 & 2.1 & 2.6 & 1.8 & 2.2 & 3.1 & 1.0 \\
\hline 3. SOE manager: middle and higher level & 30 & 0.3 & 0.6 & 0.1 & 0.1 & 0.3 & 0.2 \\
\hline $\begin{array}{l}\text { 4. SOE manager and supervisor: lower-level manager } \\
\text { and supervisor }\end{array}$ & 142 & 1.3 & 2.4 & 0.8 & 0.7 & 1.9 & 0.7 \\
\hline 5. Administrative staff and clerk & 1120 & 10.2 & 16.1 & 7.8 & 6.7 & 7.3 & 13.4 \\
\hline 6. Private business owner with 10 or more employees & 90 & 0.8 & 1.6 & 0.5 & 0.4 & 1.3 & 0.2 \\
\hline 7. Private business owner with 2-9 employees & 242 & 2.2 & 3.8 & 1.6 & 1.2 & 2.6 & 1.7 \\
\hline 8. Self-employed & 797 & 7.3 & 7.0 & 7.1 & 7.8 & 7.9 & 6.6 \\
\hline $\begin{array}{l}\text { 9. Higher-level private manager with } 10 \text { or more } \\
\text { subordinates }\end{array}$ & 215 & 2.0 & 3.4 & 1.2 & 1.4 & 2.5 & 1.4 \\
\hline 9. Lower-level private manager with 1-9 subordinates & 239 & 2.2 & 4.3 & 1.0 & 1.4 & 2.6 & 1.7 \\
\hline 10. Household contractor of rural collective economy & 4372 & 39.9 & 14.9 & 50.5 & 54.7 & 35.2 & 45.0 \\
\hline 12. Higher-level professional & 58 & 0.5 & 1.2 & 0.2 & 0.3 & 0.7 & 0.4 \\
\hline 13. Middle-level professional & 148 & 1.3 & 2.1 & 0.9 & 1.1 & 1.4 & 1.3 \\
\hline 14. Lower-level and associate professional & 601 & 5.5 & 8.0 & 4.4 & 4.0 & 4.6 & 6.5 \\
\hline 15. Skilled worker & 1084 & 9.9 & 14.1 & 9.0 & 5.9 & 10.7 & 9.0 \\
\hline 16. Unskilled worker & 1551 & 14.1 & 17.1 & 13.1 & 12.0 & 17.4 & 10.6 \\
\hline Total & 10965 & 100 & 100 & 100 & 100 & 100 & 100 \\
\hline
\end{tabular}

Table 6 shows the composition of the seven classes. The command class comprises $2.0 \%$ of all respondents. Workers constitute $24.0 \%$, with skilled workers making up 9.9\% and unskilled workers $14.1 \%$. The new upper-middle class comprises $6.7 \%$, and the new lower-middle class comprises $17.9 \%$, forming a combined proportion of $24.6 \%$ for the new middle class; small business owners and the self-employed (the old middle class) make up approximately $9.5 \%$. The two types of middle class together constitute $34.1 \%$ of all respondents. Farmers constitute $39.9 \%$.

The regional difference in class structure among the eastern, central, and western regions is significant $\left(\chi^{2}\right.$ is 1565.2 with 12 degrees of freedom and $\left.p<0.000\right)$. The eastern region has a considerably larger middle class than the central and western regions, but the central and western regions do not differ much. In the eastern region,

Table 6 Class structure in transitional China: 2010 CGSS

\begin{tabular}{|c|c|c|c|c|c|c|c|}
\hline \multirow[t]{2}{*}{ Class } & \multirow[t]{2}{*}{ Total } & \multirow[t]{2}{*}{$\%$} & \multicolumn{3}{|c|}{ Region(\%) } & \multicolumn{2}{|c|}{ Gender(\%) } \\
\hline & & & Eastern & Central & Western & Male & Female \\
\hline I. Command & 221 & 2.0 & 4.2 & 0.9 & 1.0 & 2.9 & 1.0 \\
\hline II. Upper new middle & 740 & 6.7 & 10.5 & 4.6 & 5.4 & 8.9 & 4.4 \\
\hline III. Lower new middle & 1960 & 17.9 & 28.3 & 13.2 & 12.1 & 14.4 & 21.6 \\
\hline IV. Small business owner and Self-employed & 1038 & 9.5 & 10.8 & 8.7 & 8.9 & 10.5 & 8.3 \\
\hline V. Skilled worker & 1084 & 9.9 & 14.1 & 9.0 & 5.9 & 10.7 & 9.0 \\
\hline VI. Unskilled worker & 1551 & 14.1 & 17.1 & 13.1 & 12.0 & 17.4 & 10.6 \\
\hline VII. Farmer & 4372 & 39.9 & 14.9 & 50.5 & 54.7 & 35.2 & 45.0 \\
\hline Total & 10965 & 100 & 3593 & 4653 & 2719 & 5227 & 5738 \\
\hline
\end{tabular}


$38.8 \%$ of the correspondents have become members of the new middle class, while only $17.8 \%$ in the central region and $17.5 \%$ in the west have done so. The proportion of small business owners and the self-employed (i.e., the old middle class) is also higher in the eastern region than in the central and western regions, but not by much; there is almost no difference in the proportion of small business owners and the self-employed between the central and western regions.

The gender difference in class structure is also significant (the $\chi^{2}$ is 384.2 with 6 degrees of freedom and $p<0.000$ ). Men represent a significantly higher proportion of the command class and the new upper-middle class than women, while women represent a significantly higher proportion of the lower-middle class. Among small business owners and the self-employed as well as among skilled workers, men slightly outnumber women. Among farmers, women considerably outnumber men. In general, men have a higher class status than women do.

Table 7 compares China's class structure to that of developed countries. Data indicate that, in the private sector, the proportion of private owners in China is basically close to that in developed countries though still slightly lower. Large and small business owners, who make up approximately $3 \%$, are in the dominant position in market class relations. China has a larger leadership body in the public sector than developed countries have. This part of the command class that exercises its public authority (including control rights over public assets and related revenue) is a characteristic of the current class relations and class structure. Chinese society has a larger class of the self-employed, a larger farmer class, and a relatively smaller working class. The proportion of the new middle class is comparable to that of developed countries. Small business owners and the self-employed make up a higher proportion in China's middle class than in the middle class in developed countries. They are an integral part of the Chinese middle class. The regional difference in class composition in China exceeds the commensurate differences between developed countries. The eastern region has a class structure similar to that of developed countries, with a middle class even larger than the developed countries' average. However, in the central and western regions, the new middle class makes up only $17.4 \%$ and $20.6 \%$, respectively-significantly lower than the $43.0 \%$ in the eastern region.

Table 7 Comparison of class structures in transitional China and developed countries(\%)

\begin{tabular}{|c|c|c|c|c|c|c|c|c|c|}
\hline & & $\begin{array}{l}\text { Top and } \\
\text { new middle }\end{array}$ & $\begin{array}{l}\text { Large } \\
\text { owner }\end{array}$ & $\begin{array}{l}\text { Small } \\
\text { business } \\
\text { owner }\end{array}$ & $\begin{array}{l}\text { Self- } \\
\text { employed }\end{array}$ & $\begin{array}{l}\text { Skilled } \\
\text { worker }\end{array}$ & $\begin{array}{l}\text { Unskilled } \\
\text { worker }\end{array}$ & Farmer & $\begin{array}{l}\text { Sample } \\
\text { size }\end{array}$ \\
\hline \multirow[t]{4}{*}{ China (2010) } & Total & 26.6 & 0.8 & 2.2 & 7.3 & 9.9 & 14.1 & 39.9 & 10965 \\
\hline & Eastern & 43.0 & 1.6 & 3.8 & 7.0 & 14.1 & 17.1 & 14.9 & 3593 \\
\hline & Central & 17.4 & 0.5 & 1.6 & 7.1 & 9.0 & 13.1 & 50.5 & 4653 \\
\hline & Western & 20.6 & 0.4 & 1.2 & 7.8 & 5.9 & 12.0 & 54.7 & 2719 \\
\hline The US (1980) & & 31.6 & 1.8 & 6.0 & 6.8 & 13.1 & 40.6 & - & 1493 \\
\hline Sweden (1980) & & 22.8 & 0.7 & 4.7 & 5.4 & 17.4 & 49.1 & - & 1074 \\
\hline Norway (1982) & & 27.6 & 0.8 & 2.9 & 10.3 & 21.0 & 37.4 & - & 1522 \\
\hline Canada (1982) & & 25.2 & 1.0 & 3.2 & 13.5 & 21.7 & 35.4 & - & 1779 \\
\hline The UK (1984) & & 26.7 & 2.1 & 5.1 & 6.7 & 16.6 & 42.7 & - & 1146 \\
\hline Japan (1987) & & 22.4 & 1.6 & 6.2 & 23.2 & 10.5 & 36.1 & - & 612 \\
\hline
\end{tabular}

Data of developed countries from (Wright (1997):47). For Chinese data, larger owners are excluded from the "Top and new middle." For developed countries, "small business owners and the self-employed" includes ranchers, but in the Chinese data, farmers are a separate category 
The class structure of developed countries is not "olive-shaped," as some researchers have imagined. For example, in American society, the middle-class proportion accounts for 35\% to $40 \%$, and the working-class still constitutes most of the population (Zweig 2000).

The class structure of contemporary China also differs from the "pyramid shape", as imagined by some researchers. There is a larger top class in China than in developed countries; the proportion of the new middle class is also comparable to that of developed countries. However, the proportion of China's working class is smaller than that of developed countries, and its farmers, particularly in central and western regions, far exceed the proportion of farmers in developed countries. For visualization purposes, I describe the class structure in eastern China as "olive-shaped" and that in central and western China as "gui-shaped" (it looks like the Chinese character “圭”). When we look at the entire country, the Chinese class structure is "gui-shaped."

\section{Class and income inequality}

There can be income differences between different classes since class relations are income distributive relations. The income of the command class is likely to be higher than that of the dominated classes, and the income of the middle class can sit in between. Table 8 reports the intragroup average, standard deviation, and median of each class's annual income. F-ratio $=77.7$ is highly significant $(p<0.000)$ with 6 degrees of freedom.

Both the average and median show that the command class has the highest income, and farmers have the lowest income. The income of command class is higher than that of the working-class, and the incomes of new and old middle classes sit between them. The aforementioned hypothesis is primarily supported. To more rigorously test the hypothesis, I run an OLS regression analysis of income (ln) to class dummy variables, controlling for the region (eastern, central, or western), urban-rural, gender, age, and years of education. Table 9 reports the regression results.

The income of every other class is higher than that of farmers at a high level of significance $(p<0.000)$. Taking either skilled workers or unskilled workers as the reference group, the command class has a higher income with significance $(p<0.000)$. These results further support the hypothesis that the income of the dominant class is higher than that of the subordinated class.

Taking the command class as the reference, every other class has a lower income, except for the upper-middle class. The income difference between the command class and every other class is significant $(p<0.001)$. The income difference between the new

Table 8 Annual income by class in transitional China: CGSS2010

\begin{tabular}{lllll}
\hline Class & Mean & SD & Median & $n$ \\
\hline I. Command & 111901.1 & 446539.4 & 40184.5 & 194 \\
II. Upper new middle & 40362.6 & 54224.6 & 26372.7 & 674 \\
III. Lower new middle & 24738.2 & 34982.3 & 19341.6 & 1717 \\
IV. Small business owner and self-employed & 35661.7 & 134798.7 & 14989.8 & 931 \\
V. Skilled worker & 14851.6 & 13632.3 & 12080.6 & 978 \\
VI. Unskilled worker & 14413.5 & 20152.7 & 10870.7 & 1398 \\
VII. Farmer & 6417.6 & 18408.6 & 3841.2 & 3834 \\
Total & 18901.9 & 81391.0 & 9992.5 & 9725 \\
\hline
\end{tabular}


upper-middle class and the command class is not significant $(p=0.319)$, but that between the new upper-middle class and the new lower-middle class is $(p<0.000)$. The new upper-middle class has a higher income than the old middle class with significance $(p<0.009)$, but the income difference between the new lower-middle class and

Table 9 OLS regression of logarithm of annual income on class in transitional China: 2010 CGSS

\begin{tabular}{|c|c|c|}
\hline \multirow[t]{2}{*}{ Variables } & \multicolumn{2}{|l|}{ Coefficients } \\
\hline & Model 1 & Model 2 \\
\hline \multicolumn{3}{|l|}{ Region $^{a}$} \\
\hline \multirow[t]{2}{*}{ Central } & $-0.626^{* * *}$ & $-0.511^{* * *}$ \\
\hline & -0.068 & -0.068 \\
\hline \multirow[t]{2}{*}{ Western } & $-0.092^{* * *}$ & 0.03 \\
\hline & -0.077 & -0.076 \\
\hline \multicolumn{3}{|l|}{ Urban-Rural $^{\mathrm{b}}$} \\
\hline \multirow[t]{2}{*}{ Urban } & 0.305 & $-0.256^{* * *}$ \\
\hline & -0.063 & -0.073 \\
\hline \multirow[t]{2}{*}{ Gender $^{c}$} & $1.284^{* * *}$ & $1.224^{* * *}$ \\
\hline & -0.056 & -0.056 \\
\hline \multirow[t]{2}{*}{ Age } & $0.109^{* * *}$ & $0.126^{* * *}$ \\
\hline & -0.011 & -0.01 \\
\hline \multirow[t]{2}{*}{$(\text { Age })^{2}$} & $-0.001^{* * *}$ & $-0.001^{* * *}$ \\
\hline & 0 & 0 \\
\hline \multirow[t]{2}{*}{ Education (years of schooling) } & $0.153^{* * *}$ & $0.103^{* * *}$ \\
\hline & -0.008 & -0.009 \\
\hline \multicolumn{3}{|l|}{ Class $^{d}$} \\
\hline \multirow[t]{2}{*}{ Command } & & $1.992^{* * *}$ \\
\hline & & -0.211 \\
\hline \multirow[t]{2}{*}{ Upper new middle } & & $1.777^{* * *}$ \\
\hline & & -0.134 \\
\hline \multirow[t]{2}{*}{ Lower new middle } & & $1.245^{* * *}$ \\
\hline & & -0.103 \\
\hline \multirow[t]{2}{*}{ Small business owner and self-employed } & & $1.415^{* * *}$ \\
\hline & & -0.109 \\
\hline \multirow[t]{2}{*}{ Skilled worker } & & $0.820^{* * *}$ \\
\hline & & -0.107 \\
\hline \multirow[t]{2}{*}{ Non-skilled worker } & & $0.802^{* * *}$ \\
\hline & & -0.095 \\
\hline \multirow[t]{2}{*}{ Intercept } & $4.321^{* * *}$ & $3.872^{* * *}$ \\
\hline & -0.27 & -0.272 \\
\hline$R^{2}$ & 0.166 & 0.19 \\
\hline$F$ & 276.35 & 174.92 \\
\hline df & 7 & 13 \\
\hline$N$ & 9716 & 9716 \\
\hline $\begin{array}{l}\text { Numbers in parentheses are S.E. (B) } \\
{ }^{*} p<0.05,{ }^{* *} p<0.01,{ }^{* * *} p<0.001 \\
\text { a East } \\
\text { b Rural } \\
{ }^{\text {CFemale }} \\
{ }^{\text {F Farmer }}\end{array}$ & & \\
\hline
\end{tabular}


the old middle class is not significant $(p=0.127)$. Both the new and the old middle classes have a higher income than workers, and the difference is significant $(p<0.000)$. Skilled and unskilled workers do not have a significant income difference. These findings show that, in terms of income inequality, the new and old middle classes are the intermediate classes between the command class and the working class. There is some, albeit nonsignificant, income difference among the middle classes. The income difference between the new upper-middle class and the command class is smaller than that between the new upper-middle class and the new lower-middle class, which means that the new upper-middle class is an intermediate class-between the command class and the new lower-middle class. The middle class, in general, has a larger income difference from the working class than from the command class, meaning that the middle class is not only the intermediate class between the command class and the working class but also has stronger control rights over income distribution than the working class has. These findings support my argument that class relations are also relations of the distribution of economic interests.

\section{Conclusion}

Because of China's unique institutional arrangements, we may need an alternative class framework for the transitional society of China, one that is different from the influential framework of neo-Marxist and neo-Weberian class schema for industrialized societies. Integrating the concept of the coordination mechanism and the concept of domination, I developed a class framework composed of 16 class positions and seven classes. The LCA results of the 2010 CGSS data demonstrate the strong empirical relevance of the proposed class scheme.

In contemporary China, the property rights of both economic assets and human capital are embedded in the existing structure of state authority. This fundamental institutional setting, along with the secondary institutions that derive from it, forms the institutional basis of class division. Bureaucratic coordination and market coordination are generated from these institutional arrangements, which respectively manifest as domination by virtue of authority and domination by virtue of market capacity. The duality of domination further defines the juxtaposing existence of bureaucratic class relations and market class relations. For their part, class positions are identified in terms of their rank of authority and market capacity within these class relations. As class positions are based on property rights leading to control rights over business revenue, class relations also appear as income distribution relations. As such, these intricate institutional arrangements lead class relations in transitional China to present characteristics of "domination duality" and "domination-interest duality."

In market class relations, human capital, land, economic capital, and entrepreneurship yield payoffs of wages, rent, interest, and profit, respectively. In bureaucratic class relations, factors of production generate rent through nonmarket exchanges, and the controllers of the property rights of public assets enjoy control rights over the rent. Regardless of the type of class relations, the classes in the dominant positions obtain advantages in income distribution. The proposed class framework is flexible in application, yielding various versions of class schema, and the propositions of "a dual track to the divided elite positions" and "a dual track to the divided new middle class positions" operate in transitional China. 
The class structure of contemporary Chinese society differs from the imagined "pyramid shape," just as the class structure of developed countries is not "olive-shaped," as imagined. I describe the Chinese class structure as "gui-shaped." Indeed, there are significant income differences between each class in Chinese society. The proposed class scheme can explain income inequality and supports the claim that class relations are relations of economic interest distribution. Replacing class with income hierarchy (including medium-income groups) would lead to a loss of the sociological theoretical insights embodied in the concept of class.

Although it is a widely used explanatory variable in transitional China, class is just one of many explanatory variables available to sociologists. Neither classlessness nor class determinism captures the complex reality. Class relations are only one of the many social relations, and class attributes are only one of many social attributes. In addition to interclass income differences, the variation within one class means that other sociocultural elements influence income in complicated ways. If we ignore these factors, we fall into the trap of class determinism.

\section{Supplementary information}

Supplementary information accompanies this paper at https://doi.org/10.1186/s40711-020-00116-9.

Additional file 1. Stata do-file to generate Xin Liu's class framework for society in transitional China using 2010 CGSS.

\section{Abbreviations}

CPC: The Communist Party of China; CGSS: Chinese General Social Survey; LCA: Latent class analysis; SACAC: State-owned Assets Supervision and Administration Commission

\section{Acknowledgements}

The author would like to thank scholars including Deborah S. Davis, Chunling Li, Lulu Li, Tailok Lui, Felicia F. Tian, as well as the anonymous reviewers, for their comments on this paper.

\section{Author's contributions}

The sole author contributes to this paper independently.

\section{Funding}

This study is supported by China's Talent Plan of "Cultural Masters in the Fields of Academy, Art, Art Management, and International Communication."

\section{Availability of data and materials}

The data used in this study is 2010 Chinese General Social Survey, which is publicly available from: http:/www.cnsda.org/.

\section{Author's information}

The author is the University Distinguished Professor at the Department of Sociology of Fudan University. He received PhD in Sociology from the Chinese University of Hong Kong. His research interests include social stratification and mobility, distributive justice, social capital, and community. He served as chair of the Department of Sociology at Fudan University, 2006-2018, and now as dean of The School of Social Development and Public Policy of Fudan University.

\section{Competing interests}

The author declares that there are no competing interests.

Received: 10 January 2020 Accepted: 2 March 2020

Published online: 24 March 2020

\section{References}

Breen, R. 2005. Foundations of a neo-Weberian class analysis. In In approaches to class analysis, ed. E. O. Wright. Cambridge: Cambridge University Press.

Chi, F., ed. 2014. Market decides. Beijing: China Economic Press.

Crompton, R. 2008. Class and stratification. Cambridge: Polity Press.

Erikson, R., and J.H. Goldthorpe. 1992. The constant flux. Oxford: Oxford University Press.

Ganzeboom, H. B. G., and D. J. Treiman. 2003. Three internationally standardized measures for comparative research on occupational status. In advances in cross-national comparison: A European working book for demographic and socioeconomic variables, ed. J. Hoffmeyer-Zlotnik and C. Wolf. London: Kluwer Academic / Plenum Publishers.

Goldthorpe, J. 1987. Social mobility and class structure in modern Britain. 2nd ed. Oxford: Oxford University Press. 
Goldthorpe, J. 2007. On sociology (vol. 2, 2nd edition). Stanford, CA: Stanford University Press.

Goodman, D.S. 2014. Class in contemporary China. Chicester: John Wiley and Sons Ltd..

Kornai, J. 1992. Socialist system: The political economy of communism. Princeton, NJ: Princeton University Press.

Li, C. 2005. Cleavages and fragment. Beijing: Social Sciences Academic Press.

Li, L., G. Qin, and J. Chen. 2012. The construction of authority-based stratum system: an analysis based on work situation and organizational authority. Sociological Studies 6: 46-76.

Lin, Z., and X. Wu. 2010. Institutional changes, class-structure transformation, and income inequality in China: 1978-2005. Society 6: 1-40

Liu, X. 2006. A power generation explanation of the mechanism of social stratification in contemporary China, 4-20. Autumn Issue: Social Sciences in China.

Liu, X. 2009. Institutional Basis of Social Stratification in Transitional China. In Creating Wealth and Poverty in Post-Socialist China, ed. D. Davis and F. Wang. Stanford: Stanford University Press.

Liu, X. 2010. Public power, market capacity, and the middle class location in urban China. In China Studies, ed. X. Zhou and S. Xie. Beijing: Social Sciences Academic Press.

Liu, X. 2012. Urban Chinese class structure and the location of the middle class. In In The Rising Middle Classes in China, ed. C. Li.: Paths International Ltd (UK) and Social Sciences Academic Press (China).

Lockwood, D. 1958. The blackcoated worker: a study in class consciousness. London: George Allen and Unwin.

Lu, X., ed. 2002. Research report on the class structure of contemporary China. Beijing: Social Sciences Academic Press.

Lui, T. 2015. GBCS: An answer in search of a question. Sociological Review 63: 480-492.

Marx, K. 1974. Capital, volume III, full collection of Marx and Engels Volume 25. Beijing: People's Publishing House.

Mills, C.W. 1951. White collar: the American middle classes. Oxford: Oxford University Press.

North, D.C. 1981. Structure and change in economic history. New York: Norton.

Pejovich, S. 1995. The economic analysis of institutions and systems. Boston: Kluwer Academic Publishers.

Polanyi, K. 1944. The great transformation: the political and economic origins of our time. Boston: Beacon.

Polanyi, K. 1957a. The economy as instituted process. In Trade and Market in Early Empires, ed. K. Polanyi, C. Arensberg, and H. Pearson. New York: The Free Press.

Polanyi, K. 1957b. The economy as instituted process. In Trade and Market in Early Empires, ed. K. Polanyi, C. Arensberg, and H. Pearson. New York: The Free Press.

Qian, Y., and J. Wu. 2008. Transformation in China. In Institutional Change and Economic Behaviour, ed. J. Kornai, L. Mátyás, and G. Roland. New York: Palgrave Macmillan.

Quan, H. 2017. The economics of income distribution. Shanghai: Shanghai Renmin Press.

Simmel, G. 1908. Soziologie. Leipzig: Duncker \& C. Humblot.

Sørensen, A.B. 1991. On the usefulness of class analysis in research on social mobility and socioeconomic inequality. Acto Sociologica 34: 71-87.

Sørensen, A.B. 2000. Toward a sounder basis for class analysis. American Journal of Sociology 105: 1523-1558.

Szelenyi, I. 1978. Social inequalities in state socialist redistributive economies. International Journal of Comparative Sociology 19: 63-87.

Szelenyi, I., and E. Kostello. 1998. Outline of an institutionalist theory of inequality. In The New Institutionalism in Sociology, ed. M. Brinton and V. Nee. New York: Russell Sage Foundation.

Vermunt, J., and J. Magidson. 2003. Latent class analysis. In Encyclopedia of Social Science Research Methods, ed. M. Lewis-Beck, A. E. Bryman, and T. F. Liao. London: Sage.

Vogt, K.C. 2018. The concept of the work situation in class analysis. Current Sociology 66 (6): 849-866.

Weber, M. 1978. Economy and society an outline of interpretive Ssciology. Berkeley: University of California Press.

Wright, E.O. 1979. Class structure and income determination. New York: Academic Press.

Wright, E.O. 1985. Classes. London: New Left Books.

Wright, E.O. 1997. Class counts. Cambridge: Cambridge University Press.

Wu, J. 2010. Understanding and interpreting China's economic reform. Shanghai: Shanghai Far East Publishers.

Yang, R. 2014. Mixed economy as the breakthrough for state-owned enterprise reform. Reform 5: 19-22.

Zhang, Y. 2008. Political attitude of the contemporary Chinese middle class. Social Sciences in China 2: 117-131.

Zou, M. 2015. Employment relations and social stratification in contemporary urban China: does Goldthorpe's class theory still work? Sociology 49 (6): 1133-1150.

Zweig, M. 2000. The working class majority. New York: Cornell University Press.

\section{Publisher's Note}

Springer Nature remains neutral with regard to jurisdictional claims in published maps and institutional affiliations. 